\title{
$\mathrm{CA}$ 저장을 이용한 자두 '추희'의 품질유지 및 저온장해 발생 억제
}

\author{
이은진 $^{1 \dagger} \cdot$ 최선영 ${ }^{2 \dagger} \cdot$ 조미애 ${ }^{3 *} \cdot$ 홍윤표 $^{3} \cdot$ 최지원 $^{3} \cdot$ 정대성 $^{3}$ \\ ${ }^{1}$ 서울대학교 식물생산과학부, ${ }^{2}$ 농업기술실용화재단, ${ }^{3}$ 농촌진흥청 국립원예특작과학원
}

\section{Quality Maintenance and Suppression of Chilling Injury of 'Akihime' Plum Fruits Stored under Controlled Atmosphere}

\author{
Eun Jin Lee ${ }^{1 \dagger}$, Sunyoung $\mathrm{Choi}^{2 \dagger}$, MiAe Cho ${ }^{3 *}$, YoonPyo $\mathrm{Hong}^{3}$, JiWeon $\mathrm{Choi}^{3}$, and DaeSung Chung ${ }^{3}$ \\ ${ }^{1}$ Department of Plant Science, Seoul National University, Seoul 151-921, Korea \\ ${ }^{2}$ The Foundation of Agriculture Technology Commercialization \& Transfer, Suwon 441-857, Korea \\ ${ }^{3}$ National Institute of Horticultural \& Herbal Science, Rural Development Administration, Suwon 440-706, Korea
}

\begin{abstract}
Akihime' plums picked at mature stage (50-70\% red coloration of the fruit skin) were stored at $1{ }^{\circ} \mathrm{C}$ under air or controlled atmosphere $(\mathrm{CA})$ storage regime as following $3 \% \mathrm{O}_{2}+1,3,5$, and $7 \% \mathrm{CO}_{2}$ for 50 days for the purpose of assessing the effect of CA storage on the maintenance of fruit quality and the reduction of chilling injury. Fruits stored under CA storage regime showed reduced respiration as well as ethylene production rates compared to the fruits stored in air. Quality attributes including weight loss, Hunter ' $a$ ' values, soluble solids content, titratable acidity, and firmness showed smallest changes in fruits stored under $\mathrm{CA}$ conditions except for $3 \% \mathrm{O}_{2}+7 \% \mathrm{CO}_{2}$. High incidence of physiological disorders including chilling injury, flesh browning, and decay were found in fruits stored under both air and CA of $3 \% \mathrm{O}_{2}+$ $7 \% \mathrm{CO}_{2}$. In our study, the CA storage regime of $3 \% \mathrm{O}_{2}+5 \% \mathrm{CO}_{2}$ was found the most effective for maintaining overall fruit qualities of 'Akihime' plums produced in Korea, also delayed the development of chilling injury including lack of juiciness and flesh browning. From the results, storage at $3 \% \mathrm{O}_{2}+5 \% \mathrm{CO}_{2}$ was selected as an optimal condition of 'Akihime' plum for extending storage life up to 50 days at $1{ }^{\circ} \mathrm{C}$.
\end{abstract}

Additional key words: carbon dioxide, decay, fruit quality, oxygen, storage, woolliness

\section{서 언}

자두(Prunus salicina)는 성숙 말기에 호흡량과 에틸렌 생 성량이 증가하는 호흡급등형(climacteric) 과실이다. 에틸렌 (ethylene) 발생량이 많은 자두는 수확, 저장 및 유통과정에 서 조직연화, 색 변화, 중량감소, 부패와 같은 품질변화가 일어나기 쉬워 유통기한이 짧아지므로 수확 후 취급에 주의 를 요한다(Abdi et al., 1998). 따라서 자두의 저장 중 품질변 화 억제를 위한 다양한 저장방법이 연구되어 왔는데, 저온 저장은 저장수명을 연장하기 위한 필수조건이다. 그러나 저 온저장 시 과육조직 내부의 스폰지화, 과육붕괴 및 갈변, 과 육투명화 등의 저온장해 피해가 나타날 우려가 있다(Crisosto et al., 1999). 그 중 과육갈변은 과육의 색깔이 변색되는 것 으로 표피 밑에서 시작되며, 폴리페놀(polyphenol)과 타닌 (tannin)의 효소적 산화 때문인 것으로 보고되어 있다(Dodd, 1984).

1-Methylcyclopropene(1-MCP) 처리도 상온과 저온에서 신선도를 유지시키기 위한 좋은 수확 후 처리방법으로 호흡 및 에틸렌, 세포벽연화관련 효소의 작용을 억제하여 저장된 과실의 연화와 착색을 지연시키고 저온장해 발생을 감소시 킨다(Menniti et al., 2004). 1-MCP 처리효과는 품종(Abdi et al., 1998), 처리농도(Martínez-Romero et al., 2003; Salvedor et al., 2003), 저장온도와 처리시점(Dong et al., 2002)에 따라 달라진다. 포장재의 기체투과성을 이용한 modified atmosphere

\footnotetext{
*Corresponding author: choma818@korea.kr

${ }^{\dagger}$ These authors contributed equally to this work.

※ Received 23 January 2013; Revised 17 July 2013; Accepted 13 August 2013.

(c) 2013 Korean Society for Horticultural Science
} 
저장(Diza-Mula et al., 2011; Guan and Dou, 2010), 방사선 조사(Bal and Celik, 2008)도 자두의 저장성을 향상시켰다 고 보고되었다. 수확 전 $1-2 \mathrm{mM}$ 의 푸트레신(putrescine) 처 리도 수확 후 에틸렌 생합성과 세포연화관련 효소활성을 억 제시켜 저장기간을 연장시킬 수 있다(Khan et al., 2007). Controlled atmosphere(CA) 저장 또한 자두의 수확 후 장기 저장을 위한 효과적인 방법으로 보고되어 있다(Alves et al., 2010). 그러나 노르웨이산 자두 ‘Jubileum', 'Victoria', 그리 고 'Opal' 품종을 3 주간 $2{ }^{\circ} \mathrm{C}$ 에서 $5,15,25 \%$ 이산화탄소에 각각 $\mathrm{CA}$ 저장한 결과 당도 유지에는 효과가 있었으나 오히 려 경도를 감소시켰다는 보고도 있다(Wang and Vestrheim, 2003). CA 처리는 과실의 저장력 향상에는 매우 효과적이 지만 막대한 초기투자와 시설유지 비용 등으로 인하여 국내 에서는 현재 실용화되지 못하고 있는 실정이다.

자두 '추희'는 만생종 품종으로 수확기는 9월 상순-중순 이며, 다른 품종에 비해 늦서리 피해를 입지 않고, 상대적으 로 저장성이 우수한 것으로 알려져 있다(Cho et al., 2010). 과실 평균무게는 $150-200 \mathrm{~g}$ 으로 모양은 편원형이고 과피는 바탕이 노란색이고 부분적으로 홍자색을 띠며, 단맛이 우수 하여 소비자 선호도가 높은 품종이다. 따라서 품질 좋은 적 숙기 과실을 수확하여 저장기간을 연장시킬 수 있다면 농가 의 소득증대를 기대할 수 있고, 산지유통센터(APC)로의 출 하시기 조절이 가능해져 수급과 가격안정에 도움이 될 것이 다. 근래에는 저온저장이 확산되어 '추희' 품종도 저온 저장 하는 곳이 늘어나고 있지만, 저온장해 및 부패 발생으로 유 통에 제한을 받고 있다.

따라서 본 연구에서는 우리나라에서 9월 중순에 수확하 는 만생종 자두 ‘추희'의 수확 후 품질유지 및 유통기한 연 장을 위하여 자체 제작한 $\mathrm{CA}$ 장치를 이용하여 최적의 산소 및 이산화탄소 가스조성을 설정하고, 저장 중 품질유지와 저온장해 억제를 위한 $\mathrm{CA}$ 효과를 알아보고자 하였다. 본 연 구에 사용된 $\mathrm{CA}$ 장치는 다수의 저장고를 통합 관리할 수 있으며 이동이 가능하도록 제작되었다.

\section{재료 및 방법}

\section{실험 재료}

본 실험에 사용한 공시재료는 2010년과 2012년 9월 중순 각각 경기도 이천에서 재배 및 수확된 자두 ‘추희' 품종이 다. 과피가 전체적으로 $50-70 \%$ 정도 착색된 상업적 수확시 기에 일괄 수확하였으며, 수확 후 상하거나 흠집이 없는 균 일한 크기로 선별한 후 시험에 이용하였다. 2010년에 수확 된 자두는 최적의 $\mathrm{CA}$ 기체조성 및 품질변화 양상을 조사하
기 위한 시료로 이용되었고, 2012년에 수확된 자두는 품질 변화와 더불어 CA 저장이 자두 ‘추희'의 호흡 및 에틸렌 발 생에 미치는 영향을 조사하는데 이용되었다.

\section{$\mathrm{CA}$ 저장}

$1{ }^{\circ} \mathrm{C}$ 로 설정된 저온저장고 내부에 자체 제작한 $\mathrm{CA}$ 용 밀 폐 chamber(규격 $55 \times 113 \times 100 \mathrm{~cm}$ )를 배치하였고, 각각의 chamber에는 이동식 $\mathrm{CA}$ 조절장치를 두어 내부 기체조성을 바꿀 수 있도록 하였다. CA chamber 내부로의 가스유입 및 농도조절은 gas mixer(MAP Mix 9000, PBI Dansensor, Denmark)를 이용하여 조절하였다. Fig. 1은 본 시험에 이용 된 portable $\mathrm{CA}$ 장치의 가스농도조절 원리를 보여주는 모식 도이다. CA chamber 내부의 가스농도 조절은 외부에서 설 정된 질소 및 이산화탄소 농도를 지속적으로 주입하는 방식 으로 이루어졌다. 또한, $\mathrm{CA}$ chamber 내부에 축적된 산소 및 이산화탄소 농도는 가스 측정기(MAP Check Combi, PBI Dansensor, Denmark)를 이용하여 매일 일정시간마다 측정 을 하여 저장기간 전반에 걸쳐 설정농도 $\pm 0.2 \%$ 수준이 되 도록 유지시켰다.

자두 ‘추희' 품종의 최적 $\mathrm{CA}$ 조건을 구명하고자, 수확한 자두를 $\mathrm{CA}$ 용 밀폐 chamber에 넣은 후 chamber 내부의 기 체를 각각 산소 $3 \%+$ 이산화탄소 $1 \%(\mathrm{CA} 1), 3 \%(\mathrm{CA} 2)$, $5 \%(\mathrm{CA} 3), 7 \%(\mathrm{CA} 4)$ 에 해당하는 4 가지 비율로 조성하였 으며 저장온도는 $1 \pm 0.5^{\circ} \mathrm{C}$ 로 유지하였다. 자두 $\mathrm{CA}$ 를 위한 산소 및 이산화탄소 농도는 기존에 발표된 연구 자료를 참 고하여 설정하였다(Alves et al., 2010; Ben and Gaweda, 1992a, 1992b; Menniti et al., 2006). 공기저장을 대조구로 두어 저장기간별 품질변화를 함께 비교하였다.

\section{이산화탄소 및 에틸렌 발생량}

자두를 각각의 $\mathrm{CA}$ chamber에서 꺼낸 후 $1^{\circ} \mathrm{C}$ 저장고 내

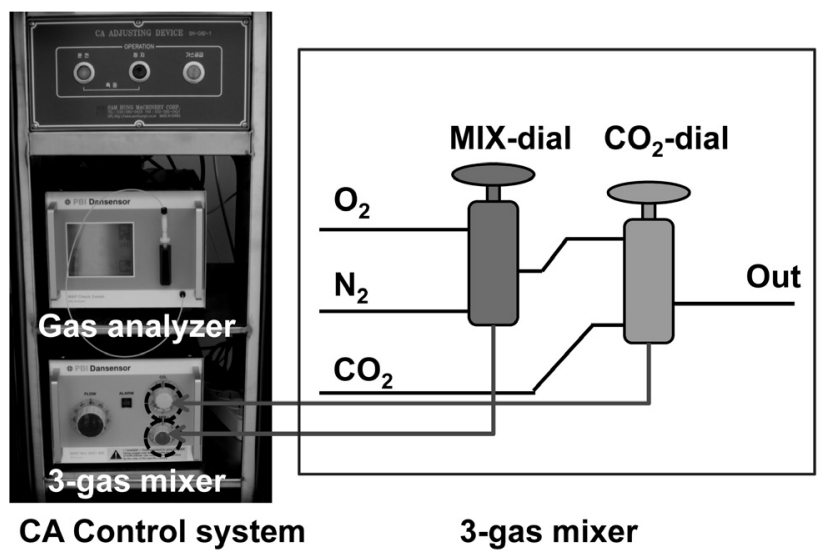

Fig. 1. Schematic diagram of portable CA control system. 
부에 22시간 두면서 공기에 완전히 노출하여 환기시켰다. 이는 CA chamber에서 일반 저장고로 꺼내어 호흡 측정 시 공기조성 변화에 의한 스트레스 반응으로 호흡과 에틸렌 발 생량이 증가할 수 있는 측면을 배제하고, 지속적인 CA 효과 에 의한 호흡 및 에틸렌 발생을 측정할 수 있도록 적응기간 을 둔 것이다. 일반적으로 $\mathrm{CA}$ 조건에서 꺼낸 즉시 이산화탄 소 및 에틸렌을 측정하면 급작스런 공기환경 변화에 의한 스트레스성 반응에 의해 발생량이 다소 높게 나타난다. 이 후 $500 \mathrm{~mL}$ 의 밀폐용기에 $300-400 \mathrm{~g}$ 과실을 넣고 $1^{\circ} \mathrm{C}$ 에서 2 시간 밀폐 후 용기내부에 축적된 가스를 $1 \mathrm{~mL}$ 주사기로 채 취하여 gas chromatography $(\mathrm{GC})$ 를 이용하여 분석하였다.

이산화탄소는 active carbon(60/80mesh)으로 충전된 column 과 thermal conductivity detector(TCD), 에틸렌 분석은 active alumina(60/80mesh)로 충전된 column과 flame ionization detector(FID)가 장착된 GC(Varian-450, Varian Inc., USA) 를 각각 이용하였다. 이산화탄소 분석조건은 injector $110^{\circ} \mathrm{C}$, oven $70^{\circ} \mathrm{C}$, detector $150^{\circ} \mathrm{C}$ 이고, 에틸렌 분석조건은 injector $110^{\circ} \mathrm{C}$, oven $70^{\circ} \mathrm{C}$, detector $200^{\circ} \mathrm{C}$ 이다. TCD와 FID 모두 수소가스를 이동상으로 사용하였으며 이산화탄소 분석을 위한 이동상 조건은 $40 \mathrm{~mL} \cdot \mathrm{min}^{-1}$, 에틸렌 분석에 이용된 이 동상은 $30 \mathrm{~mL} \cdot \mathrm{min}^{-1}$ 이다.

\section{품질조사}

중량감소율(weight loss)는 초기중량과 일정기간 경과 후 측정된 시료의 중량 차이를 초기중량에 대한 백분율(\%)로 나타내었다. 과피 색은 표준백판 $(\mathrm{L}=97.75, \mathrm{a}=-0.43, \mathrm{~b}=$ 0.29)으로 보정된 color meter(model CR-300, Minolta Corp., Japan)로 측정하여 Hunter ' $\mathrm{a}$ '값(적색도)으로 표시하였다. 경 도(firmness)는 한 과실당 적도 부위의 두 곳을 plunger 물성 측정계(TA Plus, Lloyd Instruments ${ }^{\mathrm{TM}}$, Ametek Inc., England) 를 이용하여 직경 $5 \mathrm{~mm}$ 의 probe로 측정하였고 Newton $(\mathrm{N})$ 값으로 나타내었다. 당도(soluble solids content)는 과육을 착즙 후 굴절 당도계(Atago Co., Japan)로 측정하여 ${ }^{\circ}$ Brix로 나타내었다. 적정산도(titratable acidity)는 5 배 희석한 과즙 을 $0.1 \mathrm{~N} \mathrm{NaOH}$ 로 적정하여 자두의 주요 유기산인 malic acid 함량(\%)으로 표시하였다. 자두 표면의 세포 조직학적 변화는 시료 자체의 표면을 주사전자현미경(scanning electron microscopy, Hitachi 2460, Japan)의 natural SEM mode로 촬영하여 분석하였다.

\section{관능평가}

저장 마지막 날 자두를 CA chamber에서 꺼낸 즉시 조사 하였다. 자두의 관능검사 항목은 외관(appearance), 단맛 (sweetness), 신맛(sourness), 조직감(texture), 전반적 만족도 (overall acceptability)이었다. 5점 척도(5점, 매우 좋음; 4점, 좋음; 3점, 보통; 2점, 나쁨; 1점, 매우 나쁨)를 사용하여 9명 의 사전 훈련된 패널이 평가한 후 평균값으로 나타내었다.

\section{저온장해 및 부패과 발생}

$\mathrm{CA}$ 저장의 저온장해 발생 억제 효과를 알아보기 위해 과 실의 적도부위를 절단하여 육안으로 자두 '추희' 품종의 주 된 저온장해 증상인 과즙이 없어지는 스폰지화(woolliness), 과육갈변(flesh browning), 과육붕괴(internal breakdown) 등 의 생리장해 발생을 종합적으로 고려하여 조사하였다(Candan et al., 2008; Cho et al., 2011; Lee et al., 2006; Singh and $\mathrm{Pal}, 2008)$. 또한, 부패억제 효과를 알아보기 위해서 육안으 로 곰팡이에 의해 부패된 자두의 개수를 조사하였다. 생리 장해 및 부패율은 자두 전체개수에 대하여 해당증상이 나타 난 자두 수를 백분율(\%)로 환산하여 표시하였다.

\section{통계분석}

실험결과의 통계처리는 SAS 프로그램(SAS Institute, Cary, $\mathrm{NC}, \mathrm{USA})$ 을 사용하여 분산분석(ANOVA)을 하였고, 처리간 유의차 검증은 Duncan's multiple range test(DMRT)로 $0.05 \%$ 수준에서 검증하였다. 그래프는 SigmaPlot 프로그램(Ver. 10.0, Systat Software, Inc., Chicago, IL, USA)을 사용하였다.

\section{결과 및 고찰}

\section{이산화탄소 및 에틸렌 발생량}

자두를 $3 \%$ 산소 $+1,3,5,7 \%$ 이산화탄소로 조성한 $\mathrm{CA}$ chamber에 각각 저장하면서 7일 간격으로 과실을 꺼내어 저장 시와 동일한 $1^{\circ} \mathrm{C}$ 에 24 시간 두면서 이산화탄소 및 에틸 렌 발생량을 조사하였다(Figs. 2 and 3). 호흡량은 CA 처리 구가 일반 저온저장구에 비해 다소 낮게 나타났으나 $\mathrm{CA}$ 처 리 간 호흡량 차이는 거의 없었다(Fig. 2). 저장 1 주째 대조 구에서 이산화탄소 함량이 높다가 점차 낮아지는 경향을 보 였으나, $\mathrm{CA}$ 처리구에서는 저장기간 동안 비슷한 수준을 유 지하였다. 호흡 급등형 과실을 $\mathrm{CA}$ 저장한 후 꺼내면 $\mathrm{CA}$ 잔존효과로 인해 호흡량이 감소한다(Singh and Pal, 2008). 본 시험 결과에서도 $\mathrm{CA}$ 효과에 의한 자두 ‘추희'의 호흡량 감소를 확인할 수 있었다.

에틸렌 발생량은 $1.0 \mathrm{~nL} \cdot \mathrm{g}^{-1} \cdot \mathrm{h}^{-1}$ 미만으로 모든 처리구에 서 전반적으로 낮았는데(Fig. 3), 이는 '추희' 품종이 만생종 으로 에틸렌 발생량이 낮은 품종에 속하며 또한 $1{ }^{\circ} \mathrm{C}$ 저온이 에틸렌 발생량을 낮추었기 때문인 것으로 여겨진다. 저장 2 
주 후부터 에틸렌 발생이 급상승하는 경향을 보이다가 3주 째에 최대치를 보인 후 다시 감소하는 경향을 나타냈다(Fig. 3). 대조구가 가장 높은 에틸렌 발생량을 보였으며 CA 조성 에 따라서는 이산화탄소 농도가 높을수록 에틸렌 발생량이 다소 적음을 알 수 있었다. 저장 3 주째 에틸렌 발생량은 대 조구, $1 \%$ 이산화탄소(CA 1), $3 \%(\mathrm{CA} 2)$, 그리고 $5 \%(\mathrm{CA} \mathrm{3)}$ 와 7\%(CA 4) 순으로 높았으며, $5 \%(\mathrm{CA} \mathrm{3)와} \mathrm{7 \% (CA} \mathrm{4)} \mathrm{처}$ 리간의 차이는 크지 않았다. 저장 중 높은 이산화탄소 처리 는 과실의 호흡 및 에틸렌 발생을 억제한다고 알려져 있는 데 특히 1-aminocyclopropane-1-carboxylic acid 효소 활성 억제로 에틸렌 발생을 감소시키는 것으로 보고되어 있다 (Tian et al., 1994).

한편 저장 말기인 5 주부터 모든 처리구에서 에틸렌 발생 이 점차 증가하였는데 특히 $7 \%$ 이산화탄소(CA 4) 처리구가

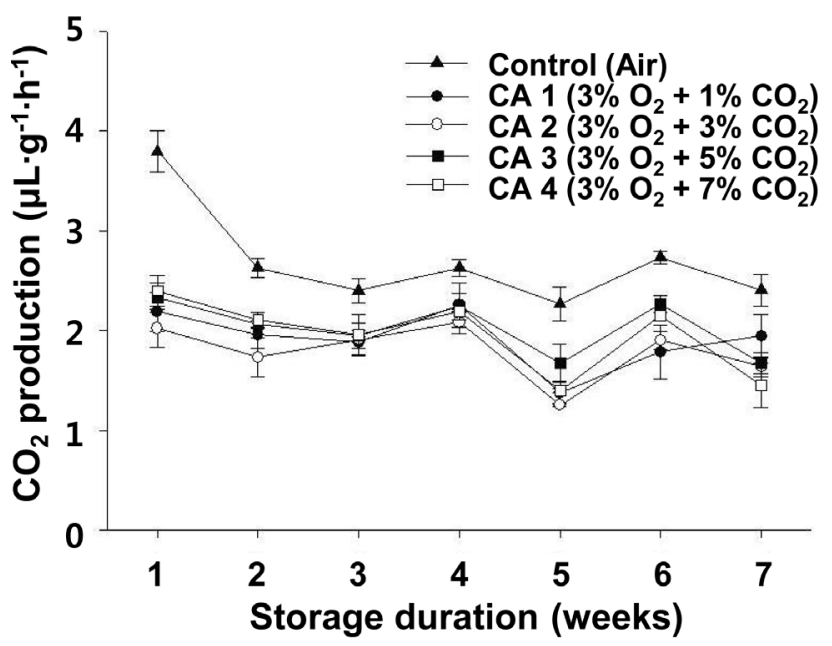

Fig. 2. Carbon dioxide production of 'Akihime' plum fruits stored under CA storage regime for 7 weeks at $1^{\circ} \mathrm{C}$. Bars indicate $\pm \operatorname{SE}(n=5)$.

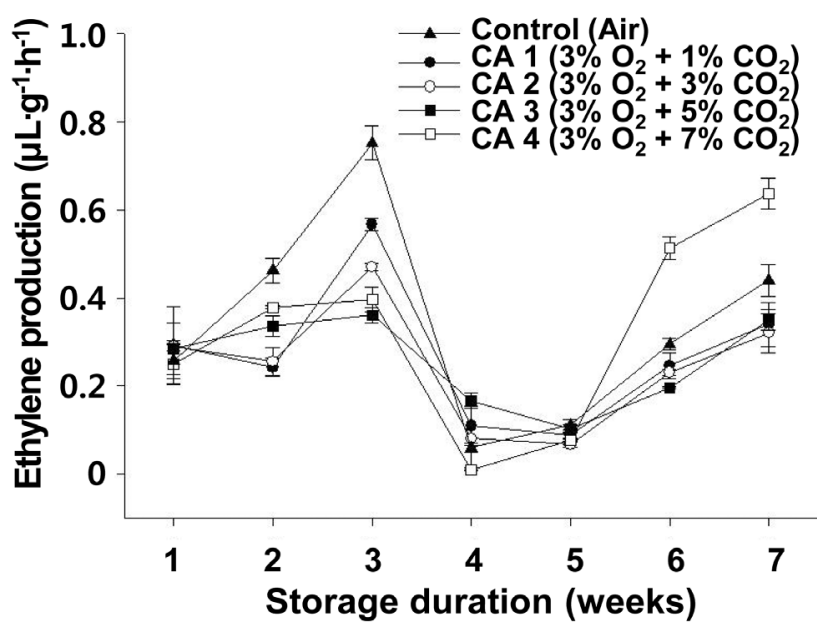

Fig. 3. Ethylene production of 'Akihime' plum fruits stored under $\mathrm{CA}$ storage regime for 7 weeks at $1^{\circ} \mathrm{C}$. Bars indicate $\pm \mathrm{SE}$ $(n=5)$.
가장 높은 에틸렌 발생 증가율을 나타내었다. 이는 고이산 화탄소에 대한 자두 ‘추희’의 스트레스성 생리반응 중 하나 로 여겨진다. 저장 중 과실의 호흡 및 에틸렌이 증가하는 원 인에는 여러 가지가 있는데 호흡 급등형 과실의 경우 성숙 에서 숙성 단계로 넘어가는 생리적 변화에 의해 호흡 및 에 틸렌 발생이 급등, 또한 과실에 부패균이 오염되었거나 온 도 및 공기조성 등의 갑작스런 환경변화에 의한 스트레스에 의해서도 호흡 및 에틸렌 발생이 증가한다.

하지만, 본 연구의 경우 $7 \%$ 이산화탄소 처리구(CA 4)에 서 저장말기 에틸렌 발생률이 큰 폭으로 증가하는 것은 과 실의 생리적 발달단계 및 부패균에 의한 것이 아니라 고농 도의 이산화탄소에 의한 스트레스성 반응으로 여겨진다. 이 유는 저장말기 과실의 부패율과 호흡률이 가장 높았던 일반 저온저장 처리구(Figs. 2 and 6)보다 CA 4 처리구가 에틸렌 발생량이 높기 때문이다. 식물조직은 높은 이산화탄소 농도 에서의 일시적 노출 시 스트레스 회복 능력이 있으나, 지속 적으로 노출되면 오히려 회복 능력이 감소하여 생리장해 증 상이 나타난다고 알려져 있다(Kader, 1986). $7 \%$ 이상의 이 산화탄소 농도는 자두 ‘추희' $\mathrm{CA}$ 저장 시 한계 이산화탄소 농도로 생각되며 고 이산화탄소 스트레스에 의해 에틸렌 발 생이 높아져 이에 따라 Fig. 6에서 나타난 것처럼 CA 4 처 리구가 다른 $\mathrm{CA}$ 처리구보다 생리장해증상 발생이 높았던 것으로 여겨진다. 비슷한 결과로 우리나라에서 재배 및 생 산된 '미백도'와 '장호원 황도'를 이산화탄소 $5 \%$ 에서 $15 \%$ 사이의 $\mathrm{CA}$ 조건에서 예비시험 한 결과 $7 \%$ 이상의 이산화 탄소 농도에서는 과육갈변 및 붕괴와 같은 생리장해증상이 증가한 바 있어 이들 핵과류의 $\mathrm{CA}$ 저장 시 이산화탄소 농도 한계치를 $7 \%$ 미만으로 설정한 바 있다(data not shown). 또 한, 청 매실 '남고'의 경우 $\mathrm{CA}$ 저장 시 적정 이산화탄소농도 한계치는 $7.5 \%$ 로 생리장해증상 없이 30 일간 저장 가능하였 다(Choi et al., 2011). 복숭아 등의 핵과류는 고이산화탄소 조건에서 비교적 내성이 강하다고 알려져 있어 $10 \%$ 이상의 고농도의 이산화탄소를 $\mathrm{CA}$ 저장 시 이용하기도 하지만, 이 는 과실의 품종, 숙도, 재배지역 및 조건에 따라 차이가 있기 때문에 저산소 및 고이산화탄소장해가 발생할 수 있는 각각 의 한계농도를 미리 설정하여 이를 바탕으로 개개의 과실에 맞는 최적의 $\mathrm{CA}$ 조성을 구명할 필요성이 있다.

\section{품질변화}

저장기간별 중량 감소율은 저장 7 주 동안 대조구가 $8 \%$ 의 감소율을 보였으나, $\mathrm{CA}$ 처리구는 중량 감소율이 $1 \%$ 내외로 일반 저온저장구에 비해 매우 낮게 나타났다(Fig. 4). CA 저 장 시 중량감소를 줄일 수 있었던 것은 $\mathrm{CA}$ 저장이 자두의 
호흡을 억제하였고(Fig. 2), CA 저장 시 밀폐된 환경이 자두 과실 주위의 상대습도를 유지하도록 하여 수분 손실을 억제 하는 것으로 생각된다. 중량감소를 줄이는 $\mathrm{CA}$ 효과는 생리 장해증상 억제 효과와 함께 $\mathrm{CA}$ 저장의 가장 큰 장점 중 하 나이며 사과나 매실 $\mathrm{CA}$ 저장 시험결과에서도 이와 유사한 결과를 나타냈다(Akubudak et al., 2009; Choi et al., 2011).

$\mathrm{CA}$ 저장 50 일 후의 품질을 수확 직후 그리고 일반 저온 저장구와 비교한 결과를 Table 1에 나타내었다. 과피의 적 색도를 나타내는 Hunter ' $\mathrm{a}$ '값은 $1{ }^{\circ} \mathrm{C}$ 저온저장으로 후숙이 지연되어 모든 처리구에서 저장 50일 동안 약 5-12의 범위

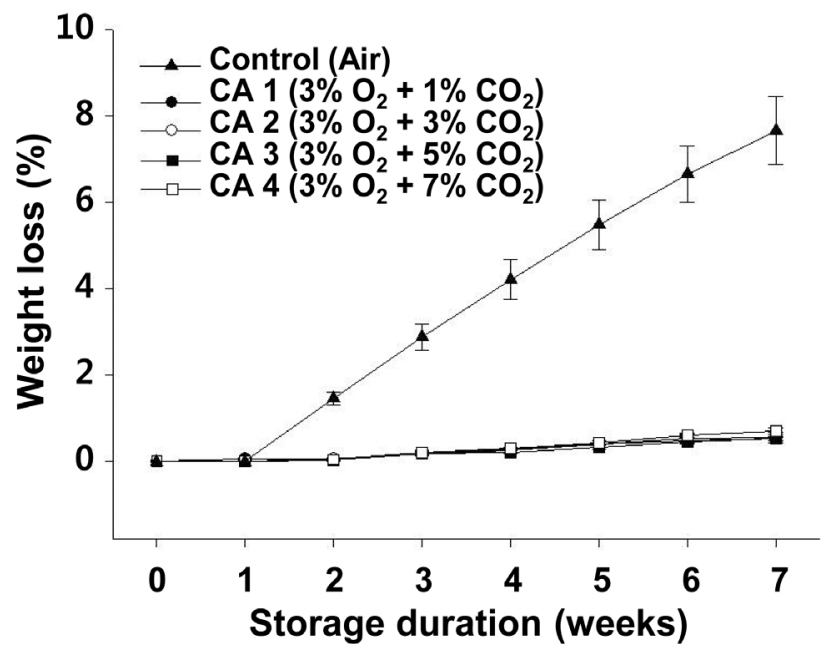

Fig. 4. Weight loss of 'Akihime' plum fruits stored under CA storage regime for 7 weeks at $1^{\circ} \mathrm{C}$. Bars indicate \pm SE (n $=5)$.
를 나타내 육안으로 보이는 붉은색으로의 변화는 크지 않았 으나, CA 저장 과실의 색도가 일반 저온 과실의 색도에 비 해 낮게 나타나 후숙이 더 지연되었음을 알 수 있었다. 경도 는 경우 초기 값인 $20.5 \mathrm{~N}$ 에서 $\mathrm{CA}$ 저장구는 $11 \mathrm{~N}$, 대조구는 $14.0 \mathrm{~N}$ 으로 낮아져, 일반 저온저장구의 경도가 $\mathrm{CA}$ 저장구에 비해 다소 높은 경도를 유지하였다. 이는 일반 저온저장구 의 경우 50 일 저장기간이 경과하면서 수분감소율이 높아져 자두의 조직이 질겨졌기 때문인 것으로 보인다. $7 \%$ 이산화 탄소(CA 4) 처리구는 다른 $\mathrm{CA}$ 처리구에 비해 낮은 경도를 나타내었는데(Fig. 3), 이는 고이산화탄소에 의한 스트레스 성 에틸렌 발생률이 높아 후숙이 촉진되었기 때문으로 보인 다. 이 결과는 $15 \%$ 의 고농도 이산화탄소 처리 시 저장 2 주 만 에 초기 경도에 비해 $50 \%$ 낮은 값을 보인 연구결과와 유사 하다(Ben and Gaweda, 1992a). 당도는 수확 직후 $11.9^{\circ} \mathrm{Brix}$ 에서 저장 50 일 후 모든 $\mathrm{CA}$ 처리구에서 $11.4-12.0^{\circ} \mathrm{Brix}$ 로 유지되었으나 일반 저온저장 당도 $13.7^{\circ} \mathrm{Brix}$ 에 비해서는 낮 은 값을 보였다. 이는 일반 저온저장 시 수분 손실이 매우 빠르게 진행되어 생체 중 내의 당 성분이 상대적으로 높아졌 기 때문이다. 적정산도는 초기치 $0.68 \%$ 에서 저장 50 일 후 $0.29-0.33 \%$ 로 감소되었으나 처리간 유의차는 없었다.

\section{과피 전자현미경 관찰}

자두 '추희'의 $\mathrm{CA}$ 저장 50 일째 과피의 구조 변화를 주사 전자현미경으로 관찰한 결과, 자두 표면의 미세구조를 비교 해보면, 대조구인 일반 저온저장 자두는 표피의 수분증발로

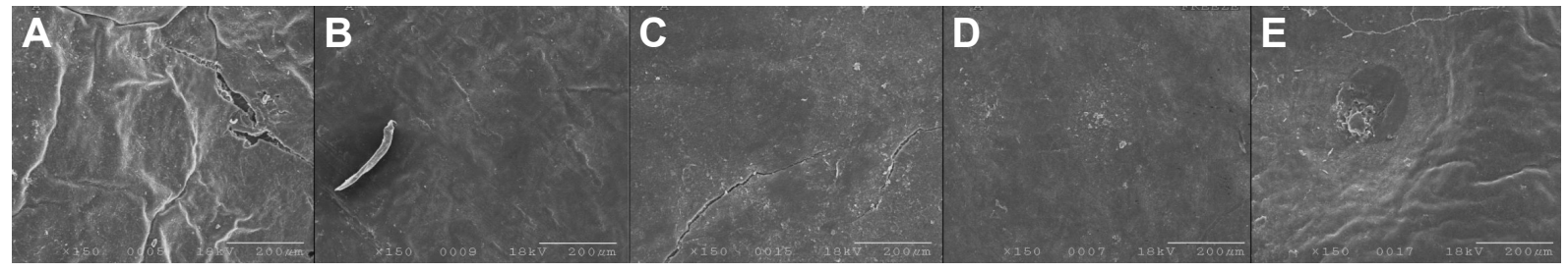

Fig. 5. Scanning electron microscopy micrographs of the fruit surfaces of 'Akihime' plums stored under CA storage regime for 50 days at $1{ }^{\circ} \mathrm{C}$. A, [Control (Air)]; $\mathrm{B}, \mathrm{CA} 1\left(3 \% \mathrm{O}_{2}+1 \% \mathrm{CO}_{2}\right) ; \mathrm{C}, \mathrm{CA} 2\left(3 \% \mathrm{O}_{2}+3 \% \mathrm{CO}_{2}\right) ; \mathrm{D}, \mathrm{CA}_{3}\left(3 \% \mathrm{O}_{2}+5 \% \mathrm{CO}_{2}\right)$; E, CA $4\left(3 \% \mathrm{O}_{2}+7 \% \mathrm{CO}_{2}\right)$.

Table 1. Changes of Hunter 'a' values, firmness, soluble solids content (SSC), and titratable acidity (TA) in 'Akihime' plum fruits stored under $\mathrm{CA}$ storage regime for 50 days at $1^{\circ} \mathrm{C}$.

\begin{tabular}{lccccc}
\hline \hline Storage & & Hunter 'a' & Firmness (N) & SSC ( ${ }^{\circ}$ Brix) & TA (\%) \\
\hline Initial & (Air) & $3.7 \mathrm{~d}^{\mathrm{z}}$ & $20.5 \mathrm{a}$ & $11.9 \mathrm{~b}$ & $0.68 \mathrm{a}$ \\
Control & $12.3 \mathrm{a}$ & $14.0 \mathrm{~b}$ & $13.7 \mathrm{a}$ & $0.33 \mathrm{~b}$ \\
$\mathrm{CA} 1$ & $3 \% \mathrm{O}_{2}+1 \% \mathrm{CO}_{2}$ & $8.5 \mathrm{~b}$ & $11.8 \mathrm{c}$ & $11.7 \mathrm{~b}$ & $0.30 \mathrm{~b}$ \\
$\mathrm{CA} 2$ & $3 \% \mathrm{O}_{2}+3 \% \mathrm{CO}_{2}$ & $8.3 \mathrm{~b}$ & $11.9 \mathrm{c}$ & $11.5 \mathrm{~b}$ & $0.29 \mathrm{~b}$ \\
$\mathrm{CA} 3$ & $3 \% \mathrm{O}_{2}+5 \% \mathrm{CO}_{2}$ & $5.9 \mathrm{c}$ & $11.9 \mathrm{c}$ & $12.0 \mathrm{~b}$ & $0.32 \mathrm{~b}$ \\
$\mathrm{CA} 4$ & $3 \% \mathrm{O}_{2}+7 \% \mathrm{CO}_{2}$ & $5.5 \mathrm{c}$ & $9.4 \mathrm{~d}$ & $11.4 \mathrm{~b}$ & $0.33 \mathrm{~b}$ \\
\hline
\end{tabular}

${ }^{z}$ Mean separation within columns by Duncan's multiple range test at $P=0.05$. 
과피가 주름지는 현상이 발생한 반면, CA $3(3 \%$ 산소 $+5 \%$ 이산화탄소) 처리구의 경우 표피의 탄력이 유지되어 수확 직후 자두 표피의 세포구조 상태를 가장 잘 유지하고 있었 다(Fig. 5). 자두 표면의 조직 검경의 결과는 저장 기간별 품 질 특성을 측정한 결과와 연관성이 있었는데, 과피가 가장 많이 주름지는 현상이 진행된 있는 $7 \%$ 이산화탄소의 $\mathrm{CA}$ 4 처리구의 경우 $\mathrm{CA}$ 처리구 중에서 가장 낮은 경도를 보였 고(Table 1), 저온장해와 부패과 발생이 상대적으로 높았다 (Fig. 6).

\section{관능평가}

$\mathrm{CA}$ 저장 50 일 후 자두 ‘추희' 과실의 중량감소율은 대조 구가 약 $8 \%$ 로(Fig. 4) 수분 감소에 의해 상대적으로 당도가 증가되는 특성을 보이고 경도 또한 $\mathrm{CA}$ 처리된 과실에 비해 상대적으로 높게 나타났지만, 대조적으로 모든 $\mathrm{CA}$ 처리구 의 과실은 $1 \%$ 에서 내외의 중량감소율을 보였고 당도는 초 기치와 비교하였을 때 변화되지 않는 특성을 보였다(Table 1). 대조구 과실의 수분감소에 의한 당도 증가가 관능평가

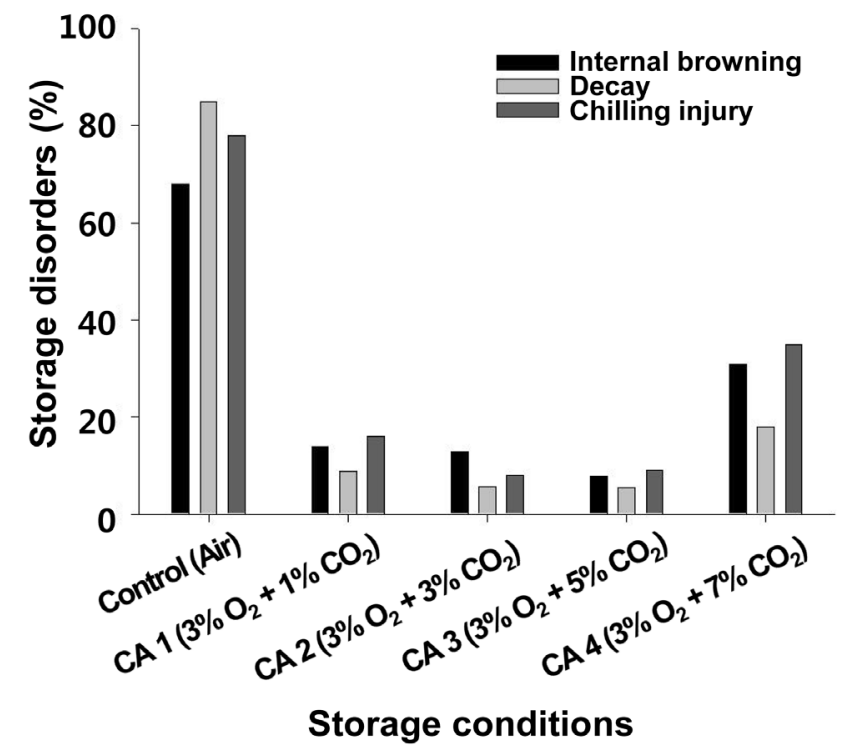

Fig. 6. Storage disorders of 'Akihime' plum fruits stored under CA storage regime for 7 weeks at $1^{\circ} \mathrm{C}$.
시 단맛 지수를 높이는 것으로는 연결되지는 않았는데, 이 는 과일의 맛은 단맛 또는 신맛 등 개별적인 맛보다는 당산 비에 의해 결정되며, 신맛이 단맛을 느끼는 데 역효과를 미 쳤기 때문인 것으로 보인다. 즉, 저장 50 일째 '추희' 과실의 당산비는 대조구, CA 1, CA 2, CA 3, 그리고 CA 4 처리에 서 차례대로 각각 $41.5,39.0,39.7,37.5$, 그리고 34.5 를 나타 내었으며, CA 4 처리를 제외한 모든 처리구의 당산비는 미 각으로 구별하기 어려운 수준에 해당하기 때문에, 관능평가 시 대조구의 단맛의 증가보다 신맛을 더 강하게 느꼈음을 의미하고 이것은 관능평가시 대조구의 신맛 지수가 1.5 로 (Table 2) 나쁨과 매우 나쁨의 중간값을 보이는 것으로 알 수 있다.

결과적으로 '추희' 과실의 저장 50 일째 품질특성(Table 1)과 관능평가(Table 2) 결과를 종합하여 보면 CA $3(3 \%$ 산 소 $+5 \%$ 이산화탄소) 처리구의 과실이 색도(Hunter 'a') 변 화가 가장 느렸고, 외관, 단맛, 신맛, 조직감과 종합적인 만 족도의 모든 평가항목에서 높게 평가되었으며, 내부 갈변도 도 낮아(Fig. 6) 품질이 가장 좋은 것으로 나타났다.

\section{저온장해 및 부패과 발생}

내부갈변, 부패, 조직의 스폰지화에 의한 저온장해 발생 률을 각각 조사한 결과, 대조구인 저온저장 자두의 생리장 해 및 부패과 발생률은 $70 \%$ 이상이었고, $\mathrm{CA}$ 처리구는 $\mathrm{CA}$ 4 를 제외하고 $20 \%$ 미만이었다(Fig. 6). 자두 '추희' 품종의 저장 중 주요 생리장해 증상은 과육갈변 및 조직의 스폰지 화로 과즙이 없어지는 저온장해현상이다(Cho et al., 2010). 본 연구결과 $\mathrm{CA}$ 저장은 이들 생리장해 현상을 감소시키는 효과를 나타내었다. $\mathrm{CA}$ 처리구 중에서 $3 \%$ 산소 $+5 \%$ 이산 화탄소(CA 3) 조성이 생리장해 및 부패 발생률이 가장 낮았 던 반면, 고농도인 7\% 이산화탄소(CA 4) 처리구에서는 저 온장해과는 $30 \%$ 이상, 부패과는 $15 \%$ 이상으로 다른 $\mathrm{CA}$ 처 리구에 비해 발생률이 높게 나타났다. 또한 대조구의 부패 율이 상대적으로 높았던 이유는 미생물이 제어되지 않는 저 장고의 대기 중에 지속적으로 노출되면서 부패미생물이 접 촉하기 쉬웠기 때문으로 생각된다(Vangdal et al., 2007).

Table 2. Sensory characteristics of 'Akihime' plum fruits stored under CA storage regime for 50 days at $1^{\circ} \mathrm{C}$.

\begin{tabular}{lcccccc}
\hline \hline Storage & & Appearance & Sweetness & Sourness & Texture & Overall acceptability \\
\hline Control & (Air) & $1.3 \mathrm{~b}^{\mathrm{z}}$ & $3.6 \mathrm{~b}$ & $1.5 \mathrm{~b}$ & $1.6 \mathrm{~b}$ & $1.1 \mathrm{~b}$ \\
$\mathrm{CA} 1$ & $3 \% \mathrm{O}_{2}+1 \% \mathrm{CO}_{2}$ & $4.6 \mathrm{a}$ & $4.3 \mathrm{a}$ & $3.9 \mathrm{a}$ & $4.3 \mathrm{a}$ & $4.1 \mathrm{a}$ \\
$\mathrm{CA} 2$ & $3 \% \mathrm{O}_{2}+3 \% \mathrm{CO}_{2}$ & $4.5 \mathrm{a}$ & $4.2 \mathrm{a}$ & $4.0 \mathrm{a}$ & $4.4 \mathrm{a}$ & $4.2 \mathrm{a}$ \\
$\mathrm{CA} 3$ & $3 \% \mathrm{O}_{2}+5 \% \mathrm{CO}_{2}$ & $4.9 \mathrm{a}$ & $4.5 \mathrm{a}$ & $4.2 \mathrm{a}$ & $4.5 \mathrm{a}$ & $4.5 \mathrm{a}$ \\
$\mathrm{CA} 4$ & $3 \% \mathrm{O}_{2}+7 \% \mathrm{CO}_{2}$ & $4.8 \mathrm{a}$ & $3.9 \mathrm{~b}$ & $3.8 \mathrm{a}$ & $4.1 \mathrm{a}$ & $3.9 \mathrm{a}$ \\
\hline
\end{tabular}

${ }^{z}$ Mean separation within columns by Duncan's multiple range test at $P=0.05$. 
자두 $\mathrm{CA}$ 저장에 관한 연구결과를 살펴보면, $1-3 \%$ 산소 농도를 주로 사용하며 산소농도 차이는 저장 중 과실품질 변화에 거의 영향을 미치지 않으나, 이산화탄소 농도에 대 해서는 다양한 이산화탄소 수준이 품질 유지에 적합하다고 보고되어 있다(Alves et al., 2010; Ben and Gaweda, 1992a, 1992b; Menniti et al., 2006; Wang and Vestrheim, 2003). $\mathrm{CA}$ 저장 시 산소와 이산화탄소의 농도조성은 과실종류, 품 종 등에 따라 다른 양상을 보이며 저장성 향상과 관련한 중 요한 인자이다. 적정농도를 벗어난 산소와 이산화탄소 처리 는 생리대사 이상에 의한 조직붕괴나 갈변 같은 여러 생리 장해를 유발할 수 있으며, 장기 보존을 위해 저온 저장을 하 지만 적절하지 못한 저장은 심각한 저온장해를 일으킬 수 있다(Crisosto et al., 1999). 본 실험에서도 자두 '추희'는 $7 \%$ 의 이산화탄소 농도에서 저온장해과 발생과 부패율이 높 아지는 것으로 나타나 품종에 따라 최적 기체 조성에 차이 가 있는 것을 알 수 있었고, ‘추희'를 CA 저장하고자 할 때 에는 이산화탄소 농도가 $7 \%$ 를 넘어가지 않도록 유의해 할 것으로 보인다. 또한 다른 품종의 자두에 대해 $\mathrm{CA}$ 저장을 시도할 경우 저장하고자 하는 품종이 저산소와 고이산화탄 소 장해에 민감한지 여부를 미리 설정하는 연구가 수행되어 야 할 것이다.

이상의 결과를 토대로 자두 ‘추희'를 $\mathrm{CA}$ 저장 시 품질유 지, 부패율 저하, 생리장해과 발생 억제 등을 종합적으로 고려 할 때 $3 \%$ 산소 $+5 \%$ 이산화탄소 $\mathrm{CA}$ 조성이 가장 적합하였 고 $1{ }^{\circ} \mathrm{C}$ 에서 약 50-60일간 저장이 가능한 것으로 사료되었다.

\section{초 록}

본 연구는 국내산 만생종 자두 품종인 '추희'의 저장성 을 향상시키고 저온장해 현상을 감소시키고자 자체 개발된 이동식 $\mathrm{CA}$ 장치를 이용하여 최적의 산소 및 이산화탄소 조 성을 구명하고자 수행되었다. 상업적 수확시기에 일괄 수확 된 자두를 $1{ }^{\circ} \mathrm{C}$ 에서 $3 \%$ 산소 $+1,3,5,7 \%$ 이산화탄소 농도 로 조성된 $\mathrm{CA}$ chamber에 각각 저장하면서 저장기간별 품 질변화, 호흡 및 에틸렌 발생, 저온장해와 부패율 발생을 조 사하였다. CA 저장은 일반 저온 저장구에 비해 과실의 호흡 량과 에틸렌 발생량은 감소시켜 과실의 품질저하 속도를 늦 추었으며 관능평가 결과도 좋게 나타났다. 특히 저온장해 발생률은 $\mathrm{CA}$ 처리구에서 일반 저온 저장구에 비해 낮게 나 타났다. 하지만 $7 \%$ 이상의 이산화탄소 농도는 오히려 자두 '추희'의 저온장해 및 부패율을 높이는 결과를 초래하였다. $\mathrm{CA}$ 조성 중 $3 \%$ 산소 $+5 \%$ 이산화탄소 조건이 과피 색도와 경도를 유지하고 과육 스폰지화와 내부갈변 등 저온장해 발
생을 지연시키는 데 가장 효과적이었다. 본 연구결과 자두 '추희'의 최적 $\mathrm{CA}$ 조건은 $3 \%$ 산소 $+5 \%$ 이산화탄소로 $1{ }^{\circ} \mathrm{C}$ 에서 약 50-60일 동안 저장이 가능하였다.

추가 주요어 : 이산화탄소, 부패, 과실품질, 산소, 저장, 스폰 지화

\section{인용문헌}

Abdi, N., W.B. McGlasson, P. Holford, M. Williams, M., and Y. Mizrahi. 1998. Responses of climacteric and suppressed-climacteric plums to treatment with propylene and 1-methylcyclopropene. Postharvest Biol. Technol. 14:29-39.

Akbudak, B., M.H. Ozer, U. Erturk, and S. Cabvusoglu. 2009. Response of 1-methylcyclopropene treated with "Granny Smith" apple fruit to air and controlled atmosphere storage conditions. J. Food Quality 32:18-33.

Alves, E.O., C.A. Steffens, C.V.T.A. Amarante, and A. Brackmann. 2010. Quality of 'Laetitia' plums as affected by temperature and storage atmosphere. Revista Brasileira de Fruticultura 32:10181027.

Bal, E. and S. Celik. 2008. Effects of postharvest UV-C treatments on quality and cold storage of cv. giant plum. J. Agr. Sci. 14:101-107.

Ben, J. and M. Gaweda. 1992a. The effect of increasing concentration of carbon-dioxide in controlled-atmosphere storage of plums cv. Wegierka-zwykla (Prunus-domestica L.). Pt. 1. firmness of plums. Acta Physiologiae Planta 14:143-150.

Ben, J. and M. Gaweda. 1992b. The effect of increasing concentration of carbon-dioxide in controlled-atmosphere storage of plums cv. Weigierka-zwykla (Prunus-domestica L). Pt. 2. Changes in the content of soluble sugars, organic-acids, and total phenols in the aspect of fruit taste. Acta Physiologiae Planta 14:151-158.

Candan, A.P., J. Graell, and C. Larrigaudiere. 2008. Roles of climacteric ethylene in the development of chilling injury in plums. Postharvest Biol. Technol. 47:107-112.

Choi, S.Y., M.A. Cho, Y.P. Hong, I.K. Hwang, D.S. Chung, and S.K. Yun. 2011. Suppression of chilling injury and maintenance of quality characteristics in Prunus mume fruits stored under controlled atmosphere. Kor. J. Food Preservation 18:143-148.

Cho, M.A., Y.P. Hong, J.W. Choi, S.K. Lee, and K.H. Kim. 2010. Aspects of chilling injury of plums cultivated in Korea during cold storage. Kor. J. Hort. Sci. Technol. 28:112.

Cho, M.A., Y.P. Hong, S,Y. Choi, D.S. Jung, B.S. Lim, S.J. Park, and S.K. Lee. 2011. The Chilling injury development and quality characteristics of 'Ooishiwase' plums (Prunus salicina L.) according to ripening stages and cold storage temperature. Kor. J. Food Preservation 18:1-6.

Crisosto, C.H., F.G. Mitchell, and Z.G. Ju. 1999. Susceptibility to chilling injury of peach, nectarine, and plum cultivars grown in California. HortScience 34:1116-1118.

Díaz-Mula, H.M., D. Martinez-Romero, S. Castillo, M. Serrano, and D. Valero. 2011. Modified atmosphere packaging of yellow 
and purple plum cultivars. 1. Effect on organoleptic quality. Postharvest Biol. Technol. 61:103-109.

Dodd, M.C. 1984. Internal breakdown in plums. Deciduous Fruit Grower August 34:355-356.

Dong, L., S. Lurie, and H.W. Zhou. 2002. Effect of 1-methylcyclopropene on ripening of 'Canino' apricots and 'Royal Zee' plums. Postharvest Biol. Technol. 24:135-145.

Guan, J.F. and S.J. Dou. 2010. The effect of MAP on quality and browning of cold-stored plum fruits. J. Food Agr. Environ. 8:113-116.

Kader, A.A. 1986. Biochemical and physiological basis for effects of controlled and modified atmospheres on fruits and vegetables. Food Technol. 40:99-104.

Khan, A.S., Z. Singh, and N.A. Abbasi. 2007. Pre-storage putrescine application suppresses ethylene biosynthesis and retards fruit softening during low temperature storage in 'Angelino' plum. Postharvest Biol. Technol. 46:36-46.

Lee, E.J., Y.P. Hong, and M.A. Cho. 2006. Physicochemical and sensory responses of 'Changhowon Hwando' peach to long-term storage at cold temperatures. Hort. Environ. Biotechnol. 47: 260-270.

Martínez-Romero, D., E. Dupille, F. Guillen, J.M. Valverde, M. Serrano, and D. Valero. 2003. 1-methylcyclopropene increases storability and shelf life in climacteric and nonclimacteric plums. J. Agr. Food Chem. 51:4680-4686.

Menniti, A.M., I. Donati, and R. Gregori. 2006. Responses of 1-MCP application in plums stored under air and controlled atmospheres. Postharvest Biol. Technol. 39:243-246.

Menniti, A.M., R. Gregori, and I. Donati. 2004. 1-Methylcyclopropene retards postharvest softening of plums. Postharvest Biol. Technol. 31:269-275.

Salvador, A., J. Cuquerella, and J.M. Martínez-Jávega. 2003. 1-MCP treatment prolongs postharvest life of 'Santa Rosa' plums. J. Food Sci. 68:1504-1510.

Singh, S.P. and R.K. Pal. 2008. Controlled atmosphere storage of guava (Psidium guajava L.) fruit. Postharvest Biol. Technol. 47:296-306.

Tian, M.S., E.W. Hewett, and R.E. Lill. 1994. Effects of carbon dioxide on ethylene forming enzyme in Japanese pear and apple. Postharvest Biol. Technol. 4:1-12.

Vangdal, E., S. Flatland, and R. Nordbo. 2007. Fruit quality changes during marketing of new plum cultivars (Prunus domestica L.). HortScience 34:91-95.

Wang, L. and S. Vestrheim. 2003. Controlled atmosphere storage of Norwegian grown plums (Prunus domestica L.). Acta Agr. Scandinavica 53:33-37. 